\title{
MOBILITY AND MIGRATION AT THE INTERSECTION OF EUROPEAN CULTURES
}

\author{
J OZ E F V L A ÁR - EGON WIE DER M N N
}

\begin{abstract}
The study deals more with the manifestations of eastern flows, especially those of the Yamna culture, in the autochthonous North Carpathian milieu. It explores the background of mobile, migration and invasive movements, and last but not least, social aspects of the trans-territorial contacts of different cultural worlds.
\end{abstract}

Keywords: Northwest Inner Carpathians, Balkans, Eurasia, Eneolithic, Early Bronze Age, mobility, migration, socio-cultural interaction.

Results of extensive archaeological research led by Slovak archaeologists in recent decades confirmed that the North Carpathian region was a real civilization crossroad of the European continent since the ancient times. In the heart of Europe (the Carpathian area; the wider territory of presentday Slovakia), various cultural influences met and intertwined, coming from closer or more distant regions, often also from the Balkan countries and the Middle East (since the emergence of agrarian civilization) and from distant Eurasian territories since the Stone Age (Bátora 2006; 2016; 2018; Bátoral Marková/Vladár 2003; Lichardus/Vladár 1996; Vladár 1970; 1973a; 1979; 1982).

Thus, in the cultural history of European communities, the territory of the Northwest Inner Carpathians played a role of strategically important intercultural intersection - the civilization crossroad of Europe, where East-West and South-North cultural flows with different socio-economic or trans-territorial basis intertwined in varying degrees and intensity. The North-South flow can probably be associated with more commercial and economic activities of local residents and foreign merchants along the Amber Road, or also with the contacts with ancient Balkan populations of those times. In the East-West flow, however, in addition to the trade-exchange, the significantly more important role was played by migration processes along the steppe (Silk) road on the background of environmental changes. The both cultural vectors the vertical and the horizontal one - were identified on a material or a mental platform here at different times and intensity.

Currently, the research of prehistoric movements is gaining ever more distinct contours in modern archaeological or interdisciplinary research. However, it seems that the deeper knowledge we have about ancient cultural interactions, also referred to by various terms such as migration, immigration, emigration, diffusion, import of thoughts, etc., the more complex the universe is. In the last two centuries, they have become a leading topic for several research schools, circles, or paradigms. Therefore, in general, in European archaeological research, mobility has become a subject of long-term interest, constantly stimulated by new knowledge, which of course also carries the necessary new ideas for exploring this complex prehistoric socio-phenomenon (Gerling et al. 2012; Gimbutas 2000; Grigoriev 2012; Hakenbeck 2008; Rassamakin 2013; Vladár/Wiedermann 2017; 2020).

However, in the course of thousands years of the Late Neolithic and Final Eneolithic, there are no significant migration processes observable in the Northwest Inner Carpathians. It is a period of stabilized structure of individual cultures, in which the appearance of foreign products indicates only their contacts with closer or more distant cultures, firstly with those in the Balkan region and at the end of the Late Neolithic with steppe Pontic and Eastern European cultural centres as well. This is particularly evidenced by the presence of foreign raw materials in areas where they do not occur at all (e. g. spondylus shells from the Eastern Mediterranean). The legitimate question is how they reached the North Carpathian territory (individual prospectors, distributors, specialists, or groups of foreign populations with a specific activity orientation).

It is certainly remarkable that as soon as at the beginning of the Eneolithic, the Volyn and Dniester flints or the horn from the Bug river basin were 'traded' in the milieu of Tiszapolgár and Bodrogkeresztúr cultures and the Lažňany culture as well (Tibava, Vel'ké Raškovce, etc.; Wiedermann 1998). Ex oriente lux! Light from the East came to the Inner Carpathian region rather in the form of exchange contacts based on rare stone industry or raw ma- 


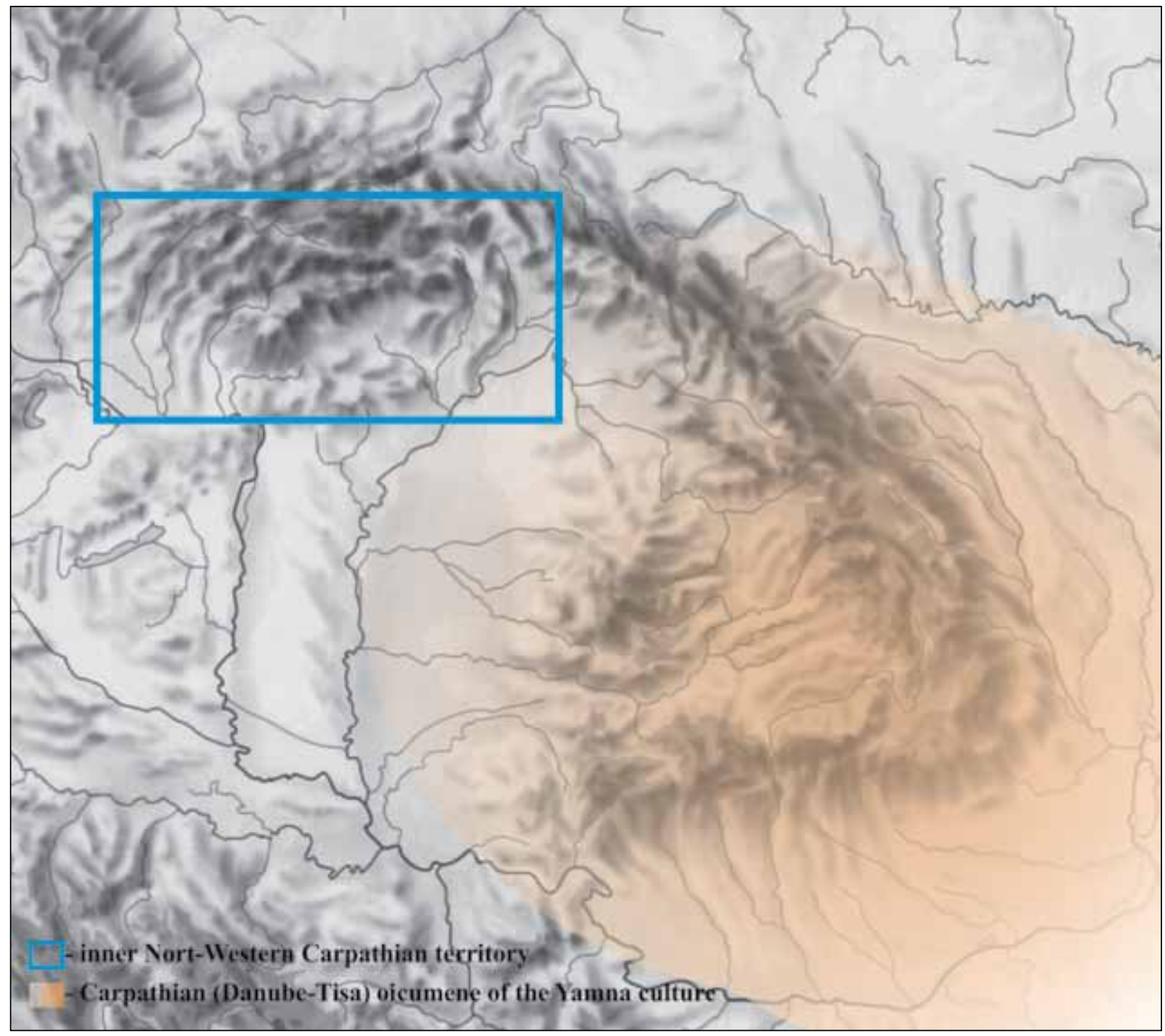

Fig. 1. The Northwest Inner Carpathian territory and the Carpathian (Danube-Tisa) oicumene of the Yamna culture (after Gimbutas 2000; Vladár/Wiedermann 2020, fig. 1).

terial. For the sake of completeness, however, it should be added that the first ever trans-territorial exchange mobility in the above mentioned areas can be identified much earlier - in the Palaeolithic period already and early contacts with the south have been proven since the emergence of agrarian civilization (e. g. spondylus shells; Nitra, Štúrovo, Branč, etc.). Certainly it was not the time of interventions of invasive ethnic groups.

In the area of the Northwest Inner Carpathians, the early latent mobile manifestations are beginning to grow into apparently migratory movements in the Late Eneolithic period, and especially in the incipient Bronze Age. This is evidenced by increasingly frequent interventions from the Pontic areas. In the context of the then stabilized domestic cultural development, represented by the Baden culture, the migration waves appeared in the Late-Baden milieu, represented mainly by people of the Yamna culture (Vladár/Wiedermann 2020,17). It was actually the era of early migration-immigration processes, announcing the end of the Late Eneolithic and the rise of the Bronze Age civilization.

Of course, the increasing appearance of foreign products cannot be described as a consequence of migration processes in the true sense of the word. The very conception of migration must therefore be seen - traditionally - as a mechanism of movement of individuals or groups in the geographical space and that of diffusion simply as a territorial dispersion of culture. Similarly, in the spirit of contemporary terminology, other concepts related to the 
spatial mobility, such as emigration and immigration, are understood and applied in the European prehistory. However, we do not perceive the term migration/diffusion (hereafter referred to as migration) in the traditional cultural-historical model as a movement of whole cultures, ethnicities and, at the end of prehistoric times, the oldest nations, but rather as an eccentric movement/shift of different large groups from their original settlements. Based on archaeological sources we assume that the primary sporadic and small groups of steppe people from Eastern European territories with different material and spiritual culture did not pose a security thread to the local population. Attractiveness of a foreign culture bringing new artefacts, impulses and innovations could just inspire the local people and increase their interest in exchange as well as induce repeated waves of migrants.

We can assume, however, that the early mobility and later migration flows to the Inner Carpathian space in the Eneolithic and the Early Bronze Age, especially from the East, could also trigger the movements of local communities to some extent. Strontium analyses proved the existence of different rates of local movements in the Early Bronze Age on both sides of the North Carpathians. Increased level of human mobility, immigration from neighbouring territories in particular, was observed in the region of Silesia. A completely different example is the situation in central Nitra river basin in Jelšovce, where the local population showed only a moderate mobility within the region (Bátora 2000; Vandkilde et al. 2015, 23).

Perhaps we will not be far from reality reiterating that the first individual or group ethnic waves of people with a 'wandering' or trade-exchange code cannot be called migration. However, they were an overture to the much more turbulent transterritorial movements later - eventually leading to the emergence of European oicumene of the Yamna culture people (Fig. 1). Its western border was the area of east Tisa river basin (Košice-Barca a. o.). This constantly multiplying migration of the Yamna people (from the North Pontic territory to the East Carpathian region) is well documented by numerous eastern attributes in the lower and upper Pontic lowlands as well as in the northeastern and southeastern territories of Poland (the East Slovakian Tumulus culture). This, of course, had to trigger 'the emergence' of a new security strategy of the autochthonous population at the turn of the Stone Age and the Early Bronze Age.

For the oldest evidence of migration processes bearing elements of mental or also physical integration of the new Yamna culture people into the autochthonous North Carpathian communities, we consider the presence of specific burial rite manifestations. It is not only the position of the deceased in graves (rhomboid or frog position of the lower limbs), but also the finds of stone cromlechs, originally perhaps with a mound embankment, or stone steles (Budinský-Krička 1967; Kalicz 1963, 10; Novotná 1987; Wiedermann 2010a, 246; 2012, 499; Vladár 2014, 243). Thus, the database of findings contains varying levels of information not only about the individual North Carpathian populations, but also about the well-organized transcultural attributes applied in the local cultural world on the background of migration-invasive movements.

Thus, investigating the causes and consequences of interference of foreign group members in the domestic milieu, raw material resources and a closely related metallurgy of copper can be one of possible explanations for their presence. In rich mining districts of the Inner Carpathians, copper was very likely extracted directly from the surface at the beginning (Kvietok et al. 2015, 38). It was not only the domestic technological experience, but 'the share' of migratory flows from the East, whose populations had advanced metallurgical experience (imports of Caucasian origin at the end of the Eneolithic, or moulds proving the local production) cannot be excluded.

Undoubtedly of East European origin is also the use of ochre dye in graves of the Eneolithic period, but especially at the burial sites of Nitra culture in the Early Bronze Age (Šiška 1964, 340; Vladár 1973b, $126,164,189)$. In this context, the phenomenon of using the corded ornament on pottery of Eneolithic cultures at the end of the Stone Age should be pointed out (Wiedermann 2010b; 2019). Its East European origin cannot be doubted at all. This is also confirmed by the invasion of cultural groups at the end of the Eneolithic as well as by significant presence on pottery of the Koštany and Nitra cultures. It was just the Pontic area, where its ancient forms were explored and documented in their stratigraphy (Lagodov'ka/Shaposhnikova/Makarevich 1962, fig. 4-18).

In addition to the above-mentioned attributes, a stone stele revealed during the research of a fortified settlement of the Otomani culture in Spišský Štvrtok is also remarkable and unique in the North Carpathian milieu finding with a possible connection to the Eurasian steppe zone. The large undecorated sandstone block measuring $101 \times 140 \times 56 \mathrm{~cm}$ and lying just under the earth surface (during the excavations) is still an exceptional example throughout the whole territory of the Otomani culture.

The unique discovery of the massive sandstone stele in Spišský Štvrtok in the High Tatras region used to be put into connection with the Mediterranean area, where monumental steles with 

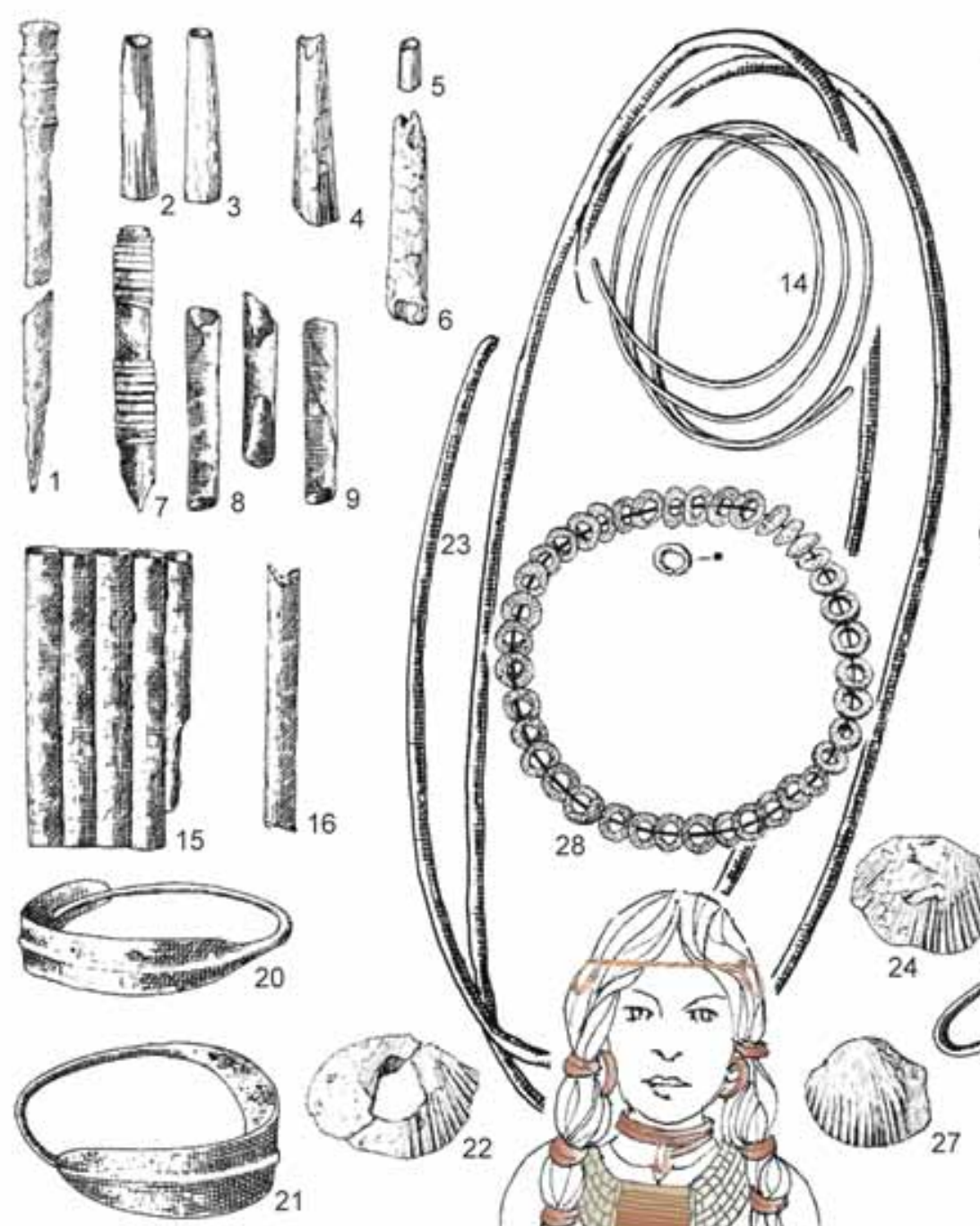

0000600010
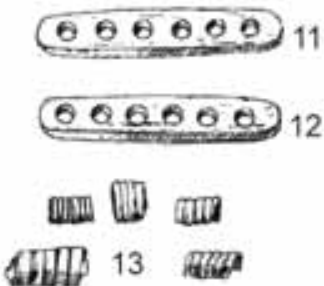
$\mathbb{P} \mathbb{D}$
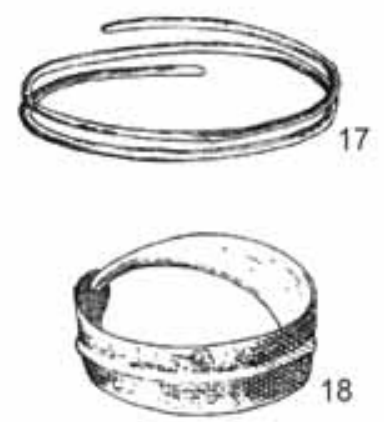

$6 \quad 28$
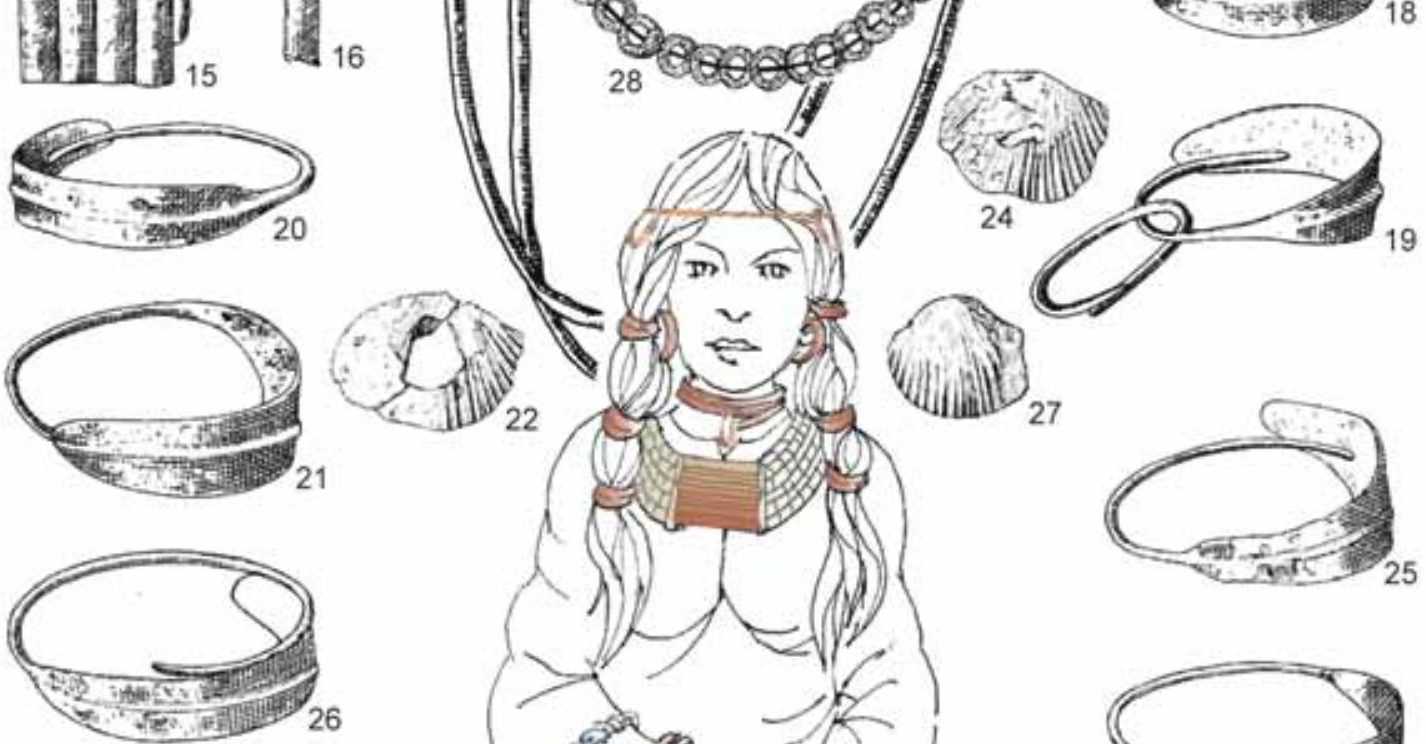

(6)

(C) (2)

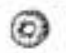

30

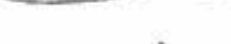

\section{(1)}
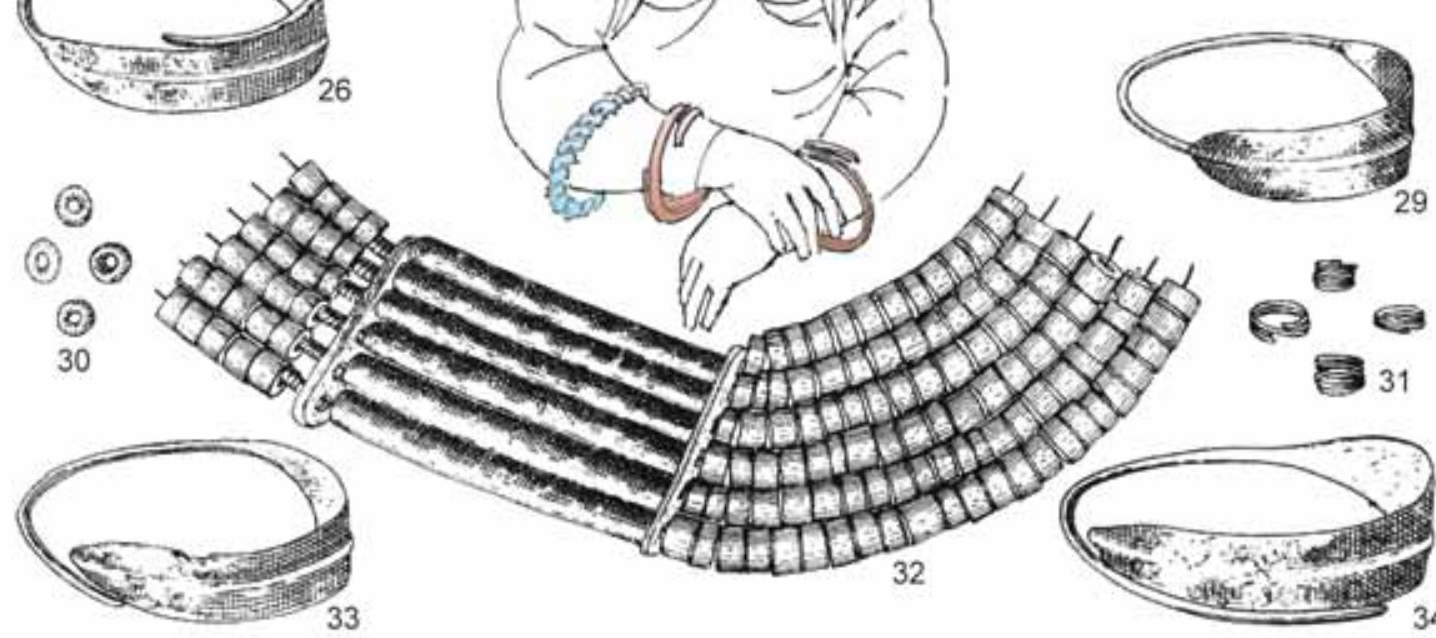

32

Fig. 2. Branč. Grave 160. A unique female grave at the burial ground of the Nitra culture with a rich set of phytomorphic jewelry (after Vladár 1973b, 48, 49, pl. XIV; XIV). Reconstruction of the hairstyle, clothing and additional decoration based on dislocation of finds in the grave (reconstruction by E. Wiedermann). 
relief decoration were used as gravestones in the shaft graves of the Mycenaean ancient aristocracy. One possible explanation of how this phenomenon appears in the Balkan cultural sphere is the migration of this element of advanced populations from the Pontic-Ural region and its translation into the ritual component of the forming Mycenaean civilization. It should also be noted that in his work Iliad, Homer already mentioned Achaeans coming to Greece from the north (Bartoněk 1976, 11).

Older than the 'Mycenaean dating' of the occurrence of stone steles in the Carpathians can be supported by the finding situation on some necropolises of the Otomani culture in the Spiš region (Vladár/Wiedermann 2020, 45). This phenomenon occurred here also in reduced or symbolic form. This is evidenced by findings at the already mentioned burial ground in Švábovce, where flysch or sandstone miniature steles and travertine stones were found in some graves. A similar use of stones was confirmed at the burial ground of the Otomani culture in Smižany. Three heart-shaped travertine segments originating in Gánovce were revealed also in a sacrificial place inside the fortified settlement in Spišský Štvrtok. The origin of andesite columns used (secondarily?) for the fortification construction of the Madarovce-North-Pannonian fortified settlement in Rybník is also noteworthy - especially in terms of using this universal phenomenon (Bátora 2015, 106, fig. 86).

Based on the results of new researches by Slovak archaeologists we can conclude that even before the Mycenaean culture had emerged at the turn of the $3^{\text {rd }}$ and $2^{\text {nd }}$ millennia $B C$, the cultural but maybe also the large-scale physical migration of eastern populations of the Sintašta-Arkaim cultural complex flew across the Pontic region up to the eastern Tisa river basin and at the final period of Otomani culture also to the territory of Northwest Inner Carpathians (Slovakia). This is also confirmed by surprising discoveries of prof. J. Bátora, who celebrates his personal jubilee, during the excavation of a fortified tell settlement of the Early Bronze Age in Vráble (Fidvár). The settlement of a circular ground plan comparable to settlements of the Sintašta culture in the South Ural region dates back to the earlier phase of the Únětice culture. Considering the chronology, it undoubtedly precedes the Mycenaean culture in Greece. This means that mobile groups of Pontic-Uralian elites led by experienced leaders could penetrate the Northwest Carpathians even before the Mycenaean culture was formed in the Peloponnese and central Greece also thanks to progressive technical innovations (wagon, harness, etc.). The motivation of migration as well as the reason for emergence of revolutionary pre-urban units of the Sintašta type in this part of Central Europe is still the open question.

The fortified settlement in Vráble-Fidvár also corrects the knowledge on the direction of cultural influences and contacts between the Central European region and especially the more remote cultural areas. The results of prof. J. Bátora in Vráble (Bátora 2013; 2015; Bátora et al. 2017) indicate that the population in that time was in contact with Eastern Europe and subsequently with the region of Eurasia and Eastern Mediterranean as soon as in the first third of the $2^{\text {nd }}$ millennium BC (e. g. the amber of Baltic origin is also found in tombs of rulers of the Mycenaean culture). The discovery that the circular built-up area in Vráble dates back to the early phase of the Únětice culture in the Northwest Inner Carpathians significantly shifts the dating of this 'city' earlier than we have anticipated until recently (2000-1750 BC).

Again, also in this context, we repeatedly believe that the explanation may perhaps be sought in the occurrence of strategic mineral resources in known North Carpathian deposits as well as in the efforts to control and to play a decisive role in the distribution of local copper ore and products. Well-organized communities of metallic prospectors certainly had a significant impact on trade-exchange relationships. At the end of Eneolithic, this is evidenced mainly by imports from the Caucasus region and later also by domestic production (casting moulds). This important European mining and production area of that time was within reach of both the Amber and the steppe (Silk) road. The willow-leaf-shaped copper artefacts of eastern origin in the Nitra culture that were made of copper from local deposits (Fig. 2; Little Carpathian region, Špania Dolina) can be an example.

In the Eurasian-Carpathian context, we consider a legged round bowl from Vítkovce (Veliačik/Javorský 1983) to be a particularly remarkable artefact of the late Eneolithic development in the Spiš region. The bowl is unique by its inside decoration. We believe that the schematized branched out depiction can symbolize the Tree of Life. The Tree of Life (Arbor vitae) motif played an important role later in Babylonian, Assyrian as well as in Greek mythology. Its literary archetype can also be found in the Book of Genesis as a tree of knowledge of good and evil, as an object symbolizing the fatal offense against the divine command in particular. Considering its style and chronology, the legged bowl from Vítkovce surprisingly has their model or inspiration at the archaeological site in Akden in Turkmenistan (Vladár/Wiedermann 2020, 53; Sarianidi 1976, fig. 6: 1).

A brilliant example of the culminating flows into the North Carpathian environment before the 

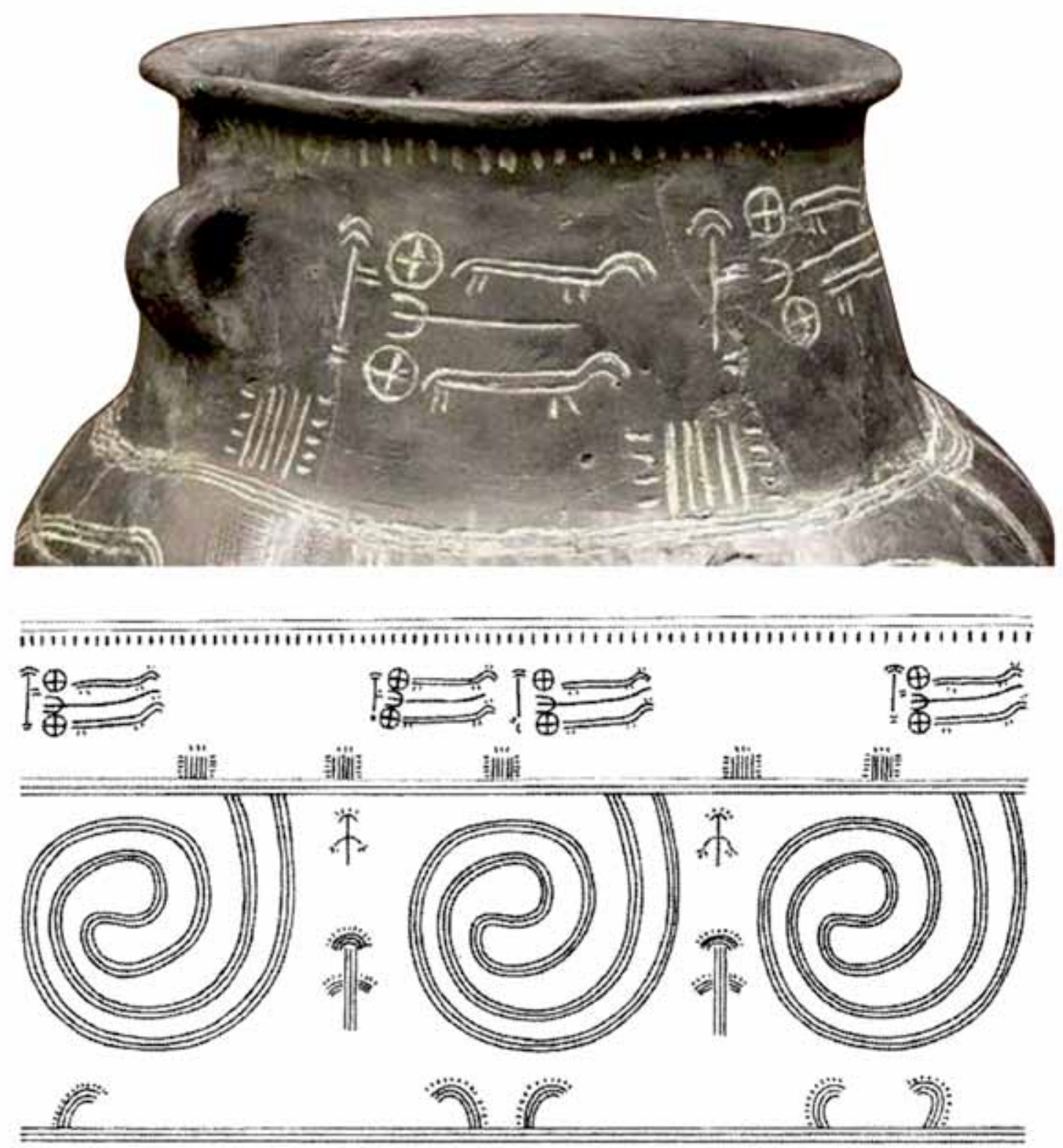

Fig. 3. Vel'ké Raškovce. Amphora with a decorative scene of a funeral ritual reminiscent of Patroclus' funeral according to Homer's description in Iliad. The Suciu de Sus culture (after Vizdal 1972, fig. 1).

emergence of tumuli cultures is represented by an amphora found in a cremation grave of the Suciu de Sus culture in Vel'ké Raškovce (Vizdal 1972, 225). It exemplifies a translation of the epic story of the emerging ancient civilization of Greece into the Carpathian cultural milieu at the turn of the Early and Late Bronze Age. The engraved picture or the funeral scene on the cremation urn from Vel'ké Raškovce resembles the description of Patroclus' funeral (Fig. 3), which together with the magnificent funeral ceremonies was perpetuated in Homer's Iliad.
The vessel from Vel'ké Raškovce very probably contained cremated remains of an important member of the clan society. Its neck is decorated with stylized war chariots and a part of the cortege accompanying the dead to the place of his eternal rest. Similar scenes with chariots occur also in remote eastern areas, e. g. on rock walls of southern Kazakhstan (Vladár 2009, 146). Other components of decoration are funeral pyre, figures and a spiral the symbol of life. The cremation scene on the funerary amphora is evidence of the related phenomena 
of ancient Greek society in the superstructure of populations living north of the Mediterranean as well as of mutual contacts between the two territories with different degrees of socio-economic development.

We are looking for the origin of the eastern attributes that appear in the Northwest Inner Carpathians at the turn of the early and younger prehistory in the area of advanced Caucasian and North Pontic civilization centres. Historical development in this context was for the first time anticipated by J. Vladár and J. Lichardus (1996). The Caucasian territory also formed a significant cultural bridge between the civilizations of Near East and Eastern Europe. It was the region of the Caucasus Mountains where the first civilization emerged at the turn of the $3^{\text {rd }}$ and $2^{\text {nd }}$ millennia BC, with which the Early Bronze Age in the North Carpathians should be associated later. In this historical era, new ethnic communities are coming from the North-from the regions above the Black Sea probably - to the territory of northern Greece, which along with autochthons contribute to the genesis to Mycenaean culture and to the development of the oldest ancient/ancient Greek civilization on our continent.

The massive ethnic movements from the East and West that culminated in the middle of the $15^{\text {th }}$ century BC and that formed the historical scene for the tumuli cultures in central Europe seem to be evidenced also by the unique iron artefact - product of metallurgy - that was found in the cult centre in Gánovce near Poprad. The iron implement, dated by radiocarbon analysis to $1465 \pm 35$ years $B C$, was originally considered an import from Anatolia controlled by the Hittites at that time. Recent research, however, points to another possible origin. One of the possibilities is its local production according to some bronze models, when a sufficient amount of iron for its production could be obtained in copper metallurgy (Furmánek 2000). Technological knowledge and skills could be imported here from the Eurasian region. In Eastern Europe, iron products at necropolises of the Yamna culture become more frequent as early as in the $3^{\text {rd }}$, or at the turn of the $3^{\text {rd }}$ and $2^{\text {nd }}$ millennia. The bimetallic axe from Orenburg, dated to the $3^{\text {rd }}$ millennium, with copper handle and iron working part can be considered a relevant find as well (Vladár/Wiedermann 2017, 248).

Undoubtedly, future research will bring new knowledge about this time of many paradoxes, twists, multi-ethnic movements and intercultural processes at the turn of the early and younger metal ages, clarifying the important role of the Yamna culture people in forming the foundations and further development of European civilization. It will certainly happen also in the territory of Northwest Carpathians, which in that turbulent period did not succumb to more substantial waves of expansion, however, it absorbed many civilization impulses from the world and retained its autochthonous character until the time of Urnfield cultures.

Archaeology of the third millennium is a syncretic science combining several disciplines from the natural sciences, social sciences and arts. The study is an attempt to analyze as completely as possible the transcultural processes between the Eurasian (especially) and Inner Carpathian worlds in the Eneolithic and the Early Bronze Age. In the field of prehistory, several levels of meaning and interpretation possibilities of this undoubtedly serious phenomenon are pursued. The character, extent and time and space of possible prehistoric mobilities and migration-invasive community movements from the Mediterranean region, but above all from the Eurasian steppe zone to Central Europe are reconstructed on the basis of archaeological sources. Their response is indicated by several attributes and identifiers present in the territory of the Northwest Inner Carpathians, which either directly or their original models are very probably of foreign origin (kurgan, ochre, corded ornament, stone stele, tree of life, houses of the dead, one-edged axes, animal graves, etc.).

The study also presents the authors' reflections on the topic, especially since the emergence of the Yamna culture oicumene in the area of the Lower Danube - North Tisa river basins. It deals with the interactions of the local and eastern environment, in particular with the share of the foreign component in the visible changes of the local cultural-historical background (emergence of fortified settlements in the Baden culture, formation of hetero-communities as well as later demise of fortified settlement forms in the Early Bronze Age). It explores the nature and content of the initial migration waves from the early trade-exchange mobilities till the more intensive migration or invasion processes and, at the end, the responses of the ancient civilization in the prehistoric intersection of European cultures. 


\section{LITERATURE}

Bartoněk 1976 - A. Bartoněk: Odysseové na mořích historie. Praha 1976.

Bátora 2000 - J. Bátora: Das Gräberfeld von Jelšovce/Slowakei. Ein Beitrag zur Frühbronzezeit im nordwestlichen Karpatenbecken. Teil 1-2. PAS 16/1-2. Kiel 2000.

Bátora 2006 - J. Bátora: Štúdie ku komunikácii medzi strednou a východnou Európou v dobe bronzovej. Bratislava 2006.

Bátora 2013 - J. Bátora: The settlement structure problem and the end of fortified settlements from the final period of Early Bronze Age in Slovakia. In: H. Meller/ F. Bertemes/H. R. Bork/R. Risch (Hrsg.): 1600 - Kultureller Umbruch im Schatten des Thera-Ausbruchs? Tagungen des Landesmuseums für Vorgeschichte. Landesamt für Denkmalpflege und Archäologie Sachsen-Anhalt 9. Halle (Saale) 2013, 373-386.

Bátora 2015 - J. Bátora: Osídlenie. In: V. Furmánek (ed.): Staré Slovensko 4. Doba bronzová. Nitra 2015, 101-108.

Bátora 2016 - J. Bátora: The Question of the Presence of the Yamnaya and Catacomb Culture in the Area of the Middle Danube and North Carpathians. In: A. Zanoci (Hrsg.): Mensch, Kultur und Gesellschaft von der Kupferzeit bis zur frühen Eisenzeit im Nördlichen Eurasien. Beiträge zu Ehren zum 60. Geburtstag von Eugen Sava. Chisinau 2016, 103-115.

Bátora 2018 - J. Bátora: Slovensko v staršej dobe bronzovej. Bratislava 2018.

Bátora/Marková/Vladár 2003 - J. Bátora/K. Marková/J. Vladár: Die Glockenbecherkultur im Kontext der kulturhistorischen Entwicklung in der Südwestslowakei. In: J. Czebreszuk/M. Szmyt (eds.): The Northeast Frontier of Bell Beakers. Oxford 2003, 255-264.

Bátora et al. 2017 - J. Bátora/P. Tóth/K. Rassmann/N. Müller-Scheeßel: Vráble-Fidvár - centrálne sídlisko európskeho významu. Osídlenie zo staršej doby bronzovej. In: Sedem decénií Petra Romsauera. Studia Historica Nitriensia 21. Supplementum - mimoriadne číslo časopisu venovanéživotnému jubileu prof. Petra Romsauera. Nitra 2017, 19-33.

Budinský-Krička 1967 - V. Budinský-Krička: Východoslovenské mohyly. Slovenská archeológia 15, 1967, 352-355.

Furmánek 2000 - V. Furmánek: Eine Eisensichel aus Gánovce. Zur Interpretation des ältesten Eisengegenstandes in Mitteleuropa. Prähistorische Zeitschrift 75, 2000, 153-160.

Gerling et. al. 2012 - C. Gerling/E. Bánffy/J. Dani/K. Köhler/G. Kulcsár/A. W. G. Pike/V. Szeverényi/V. Heyd: Immigration and Transhumance in the Early Bronze Age Carpathian Basin: The Occupants of a Kurgan. Antiquity 86, 2012, 1097-1111.

Gimbutas 2000 - M. Gimbutas: Das Ende Alteuropas. Der Einfall von Steppennomaden aus Südrußland und die Indogermanisierung Mitteleuropas. Budapest 2000.

Grigoriev 2012 - S. Grigoriev: Migrations and their role in culture genesis in Eurasia. In: V. A. Aljokšin (ed.): Cultures of the steppe zone of Eurasia and their interaction with ancient civilizations. Materials of the International conference dedicated to the 110th birth anniversary of the outstanding Russian archaeologist Mikhail Petrovich Gryazanov. St. Petersburg 2012, 40-49.

Hakenbeck 2008 -S. Hakenbeck: Migration in Archaeology: Are We Nearly There Yet? Archaeological Review from Cambridge 23, 2008, 9-26.

Kalicz 1963 - N. Kalicz: Die Péceler (Badener) kultur und Anatolien. Budapest 1963.
Kvietok et al. 2015 - M. Kvietok/S. Jeleň/V. Šmejkal/A. Sitár: Vytlkaná med' v slovenskom praveku. In: J. Labuda (ed.): Argenti Fodina 2014. Banská Štiavnica 2015, 37-42.

Lagodov'ska/Shaposhnikova/Makarevich 1962 -O. F. Lagodovs'ka/O. G. Shaposhnikova/M. D. Makarevich: Mikhajlivs'ke poselennya. Kijv 1962.

Lichardus/Vladár 1996 - J. Lichardus/J. Vladár: Karpatenbecken-Sintashta-Mykene. Ein Beitrag zur Definition der Bronzezeit als historischer Epoche. Slovenská archeológia 44, 1996, 25-93.

Novotná 1987 - M. Novotná: „Die Kultur der ostslowakischen Hügelgräber und ihre Beziehungen zu den benachbarten Gebieten." In: D. Srejović/N. Tasič (Hrsg.): Hügelgräberbestattung in der Karpaten-Donau-Balkan-Zone während der äneolithischen Periode. Internationales Symposium Donji Milanovac 1985. Beograd 1987, 91-97.

Rassamakin 2013 - Y. Rassamakin: From the Late Eneolithic Period to the Early Bronze Age in the Black Sea Steppe: What is the Pit Grave Culture (Late Fourth to Mid-Third Millennium BC)? In: V. Heyd/G. Kulcsár/V. Szeverényi (eds.): Transitions to the Bronze Age. Interregional Interaction and Socio-Cultural Change in the Third Millennium BC Carpathian Basin and Neighbouring Regions. Budapest 2013, 113-138.

Sarianidi 1976 - V. I. Sarianidi: Material'naya kul'tura Yuzhnogo Turkmenistana v period ranney bronzy. In: V. I. Masson/E. Atagarryev (red.): Pervobytny Turkmenistan. Ashabad 1976, 82-111.

Šiška 1964 - S. Šiška: Pohrebisko tiszapolgárskej kultúry v Tibave. Slovenská archeológia 12, 1964, 293-352.

Vandkilde et al. 2015 - H. Vandkilde/S. Hansen/K. Kotsakis/K. Kristiansen/J. Müller/J. Sofaer/M. L. S. Sørensen: Cultural Mobility in Bronze Age Europe. In: P. Suchowska-Ducke/S. S. Reiter/H. Vandkilde (eds.): Forging Identities. The Mobility of Culture in Bronze Age Europe. Report from a Marie Curie Project 2009-2012 with Concluding Conference at Aarhus University, Moesgaard 2012. Oxford 2015, 5-37.

Veliačik/Javorský 1983 - L. Veliačik/F. Javorský: Záchranný výskum na hradisku Tureň vo Vítkovciach. Archeologické rozhledy 35, 1983, 143-147.

Vizdal 1972 - J. Vizdal: Erste bildliche Darstellung eines zweirädrigen Wagens vom Ende der mittleren Bronzezeit in der Slowakei. Slovenská archeológia 20, 1972, 223-231.

Vladár 1970 - J. Vladár: Zásahy cudzích kultúrnych skupín na území Slovenska. In: A. Točík (ed.): Slovensko v mladšej dobe kamennej. Bratislava 1970, 231-234.

Vladár 1973a - J. Vladár: Osteuropäische und mediterrane Einflüsse im Gebiet der Slowakei während der Bronzezeit. Slovenská archeológia 21, 1973, 253-357.

Vladár 1973b - J. Vladár: Pohrebiská zo staršej doby bronzovej v Branči. Bratislava 1973.

Vladár 1979 - J. Vladár: Das Karpatenbecken, das Kaukasusgebiet und das östliche Mittelmeergebiet in der mykenischen Schachtgräberzeit. In: K. Herman/J. Vladár (éds.): Rapports, co-rapports, communications tchécoslovaques pour le IV Congrès de l'Assotiation internationale d'Etudes du Sud-Est Européen. Praha 1979, 15-50.

Vladár 1982 - J. Vladár: Probleme der Bedeutung fremder Kulturimpulse in der Entwicklung der alterbronzezeitlichen Zivilization im Gebiet der Slowakei. In: A. Aspes (ed.): Atti de X Simposio Internationale sulla finé del Neolitico 
e gli imizi dell' età del Bronzo in Europa. Lazise - Verona 8-12 aprile 1980. Verona 1982, 199-205.

Vladár 2009 - J. Vladár: Náboženské predstavy pravekého ludstva na Slovensku. In: A. Cerveňák/L. Zrubec/ J. Vladár: Moje/naše najmilšie. Nitra 2009, 151-160.

Vladár 2014 - J. Vladár: Praveké mestá z doby bronzovej. Spišský Štvrtok a Košice-Barca. Musaica 28, 2014, 15-37.

Vladár/Wiedermann 2017 - J. Vladár/E. Wiedermann: From the Pontic Steppes to the West - to the Carpathian Autochthones. In: Sedem decénií Petra Romsauera. Studia Historica Nitriensia 21. Supplementum - mimoriadne číslo časopisu venované životnému jubileu prof. Petra Romsauera. Nitra 2017, 237-253.

Vladár/Wiedermann 2020 - J. Vladár/E. Wiedermann: The World behind the World. Berlin 2020.

Wiedermann 1998 - E. Wiedermann: Počiatky medziregionálnych obchodno-výmenných vztahov v praveku Ponitria. Studia Historica Nitriensia 7, 1998, 47-61.
Wiedermann 2010a - E. Wiedermann: Šnúrová epistéma - kultúrny kód spletených povrázkov. Slovenská archeológia 58, 2010, 243-258.

Wiedermann 2010b - E. Wiedermann: Idea of Cord. In: J. Šuteková/P. Pavúk/P. Kalábková/B. Kovár (eds.): Panta $R$ hei. Studies on the Chronology and Cultural Development of South-Eastern and Central Europe in Earlier Prehistory Presented to Juraj Pavúk on the Occasion of his $75^{\text {th }}$ Birthday. Bratislava 2010, 491-505.

Wiedermann 2012 - E. Wiedermann: Populácie šnúrového ornamentu v severozápadnom vnútrokarpatskom teritóriu. In: R. Kujovský/V. Mitáš (ed.): Václav Furmánek a doba bronzová. Zborník $k$ 70. narodeninám. Nitra 2012, 397- 414 .

Wiedermann 2019 - E. Wiedermann: Corded Identity. In: Sedem kruhov Jozefa Bujnu. Studia Historica Nitriensia 23. Supplementum. Nitra 2019, 207-2013.

Manuscript accepted 9. 8.2020

Translated by Ludmila Vaňková

prof. PhDr. Jozef Vladár, DrSc. Archeologický ústav SAV

Akademická 2

SK - 94921 Nitra

jozef.vladar@savba.sk

prof. PhDr. Egon Wiedermann, CSc.

Katedra muzeológie

Filozofická fakulta

Univerzita Konštantína Filozofa v Nitre

Hodžova 1

SK - 94901 Nitra

ewiedermann@ukf.sk

\title{
Mobility a migrácie na križovatke európskych kultúr
}

\author{
Jozef Vladár - Egon Wiedermann
}

\begin{abstract}
SÚHRN
Štúdia sa zaoberá kultúrnymi interakciami eurázijských (predovšetkým) a vnútrokarpatských svetov v neskorej dobe kamennej a staršej doby bronzovej. Prezentuje širšie autorské úvahy k danej téme, najmä v čase od vzniku dolnodunajsko-severopotiskej oikumeny jamovej kultúry. V zornom poli prehistórie zahrňujúcej širšie bádatel'ské pole (archeológia, história, antropológia, etnológia, umenoveda, či filozofia) sa sledujú viaceré významové roviny a interpretačné možnosti tohto procesu, predovšetkým na báze archeologických prameňov (archeológia migrácií). Skúma sa charakter, rozsah, ako aj čas a priestor možných prehistorických mobilít a migračno-inváznych pohybov z mediteánnej oblasti, obzvlášt však spoločenstiev z eurázijskej stepnej zóny do

centrálnej Európy. Ich prítomnost’ na teritóriu severozápadných vnútorných Karpát signalizujú viaceré atribúty a identifikátory inokrajinného rázu (kurhan, okrové farbivo, šnúrový ornament, kamenné stély, zoomorfná plastika, fytomorfná industria, antické prvky a pod.)

Archeológia migrácií sústred’uje pozornost predovšetkým na rozrastajúce sa množstvo transkultúrnych prvkov, ktoré nemožno jednoznačne priradit' $\mathrm{k}$ miestnym severokarpatským komunitám. Naznačujú existenciu zložitých prehistorických sociofenoménov od raných obchodno-výmenných mobilít a neskorších migračných, či inváznych procesov až po rané ohlasy antickej civilizácie $\mathrm{v}$ prehistorickom priesečníku európskych kultúr.
\end{abstract}


